\title{
Challenges in postharvest management of fungal diseases in fruits and vegetables - A review
}

\author{
Siddarth N. Rahul*', Kamal Khilari ${ }^{1}$, Sushma Sagar ${ }^{2}$, Sorabh Chaudhary², Sudhir \\ Kumar $^{3}$, Nitika Vihan ${ }^{4}$, Akash Tomar ${ }^{4}$
}

${ }^{1}$ Department of Plant Pathology, ${ }^{2}$ Department of Ag. Biotechnology, ${ }^{3}$ Department of Entomology, ${ }^{4}$ Department of RDT, College of Biotechnology, S. V. P. U. A. \& T. Meerut, Uttar Pradesh, E mail: sagar4499@gmail.com

\begin{abstract}
After the fruits and vegetables are harvested, the value of fruits and vegetables is added in successive stages and remain in living phase. Losses due to postharvest disease may occur at any time during postharvest handling. The aim of postharvest management of diseases is to maximise the quality and storage value. The postharvest products are living and respiring materials, and from field to eating, several factors influence quality and there are many fungal and bacterial pathogens which affect them. The quality of these delicate products peaks at harvest when they are green and crisp, but during handling and storage their quality attributes may be deteriorated, resulting in products of inferior quality when they reach the consumers. Important genera of anamorphic postharvest pathogens include Penicillium, Aspergillus, Geotrichum, Botrytis, Fusarium, Alternaria, Colletotrichum, Dothiorella, Lasiodiplodia and Phomopsis. Some of these fungi also form ascomycete sexual stages. There should be integrated approaches to management the postharvest diseases to reduce the qualitative and quantitative loss of vegetables and fruits as fresh and during storage.
\end{abstract}

Keywords: Management strategies, Postharvest fungal pathogens, Diseases.

Paper cited: Rahul, Siddarth N., Khilari, Kamal., Sagar, Sushma., Chaudhary, Sorabh., Kumar, Sudhir., Vihan, Nitika and Tomar, Akash. (2015). Challenges in Postharvest Management of Fungal Diseases in Fruits and Vegetables - A review. South Asian Journal Food Technol. Environ. 1(2):126- 130.

Postharvest losses of fruits and vegetables vary from an estimated 5 percent to more than 20 percent which can be more than 50 percent in the developing countries (Cappellini and Ceponis, 1984; Eckert and Ogawa, 1985). Although India is the largest producer of fruits in the world, its production per capita is only about $100 \mathrm{~g}$ per day. Between 20 and $30 \%$ of total fruit production goes to waste owing to spoilage at various steps of the postharvest chain, reducing per capita availability of fruits to around $80 \mathrm{~g}$ per day which is almost half the requirement for a balanced diet. The fruit processing sector has grown at a rate of about $20 \%$ per annum. India is the second largest producer of vegetables in the world, ranking next to China, and accounts for about $15 \%$ of global vegetable production. It is estimated that between 30 and $35 \%$ of India's total vegetable production is lost because of poor postharvest practices. Less than $2 \%$ of the total vegetable production in the country is commercially processed as compared to $70 \%$ in Brazil and $65 \%$ in the USA. Postharvest losses have been managed mainly through postharvest fungicides (Eckert and Ogava 1985, 1988) and, to a lesser degree, through postharvest management practices to reduce inoculum or effective management of the cold chain system (keeping the fruits and vegetables at low temperatures, which greatly reduce pathogen growth, from harvest to retail). However, postharvest use of fungicides has been increasingly curtailed by the development of pathogen resistance to many key fungicides (Holmes and Eckert, 1999; Prusky et al., 1985; Rosenberger and Meyer, 1981; Vinas et al., 1991). The lack of the fungicide replacement and complaint of the public regarding the harm full effect of the fungicides to the human health there has to be the alternatives of the fungicides or should be less use of fungicides (Gullino and Kuijpers, 1994; Ragsdale and Sisler, 1994).

\section{Management strategies}

The diseases presented in the Table 1 are very common in the vegetables and fruits. They appear in very devastating form when the pathogens gets their environment condition favoured to them. Before the management of the postharvest diseases it should be kept in the mind that the any control measure to eliminate the microbes should be environment and consumer 
friendly. It should not have the human health problems, which is the most concerning problems in consuming the fruits and vegetables this time.

\section{Postharvest disease control and Prevention}

Prevention of the injury: Various types of physical damage (surface injuries, impact bruising, and vibration bruising and so on) are major contributors to deterioration. Browning of damaged tissues results from membrane disruption, which exposes phenolic compounds to the polyphenol oxidase enzyme. Mechanical injuries not only are unsightly but also accelerate water loss, provide sites for fungal infection, and stimulate $\mathrm{CO}_{2}$ and ethylene production by the commodity. When fruits are harvested too late for example, inherent physiological developments render them more susceptible to injury as when subjected to rough handling at the time of harvest and subsequently during sorting, grading and transportation.

Cleaning of the products: After harvest before packing or marketing individual fruits and vegetables should be washed and clean in abundant flow of clean water to remove plant debris, trash, latex and pathogen inoculum which are responsible for causing diseases in transit. There are many chemicals which can be as the disinfectant i.e. Chlorine, Chlorine Dioxide, Acidified hydrogen peroxide etc.

Hot water treatment: Hot water treatment is promising and has been used with success in eradicating or suppressing the development of fungi/bacteria on the fruit surface as well as those situated just below the surface as a result of pre harvest infection. The study of Jacobi et al., (2001) and Kader, (2002) concluded that $53^{\circ} \mathrm{C}$ hot water for $5 \mathrm{~min}$, vapour at $47^{\circ} \mathrm{C}$ for $15-20 \mathrm{~min}$ were a successful treatment. Tsai (1969) has find that Hot water treatment at $49^{\circ} \mathrm{C}$ for 20 minutes and washing of fruits with water immediately after harvesting minimize the losses in papaya (Pathak, 1980).

Heated forced air treat/Aerated steam/hot air: Recently heated forced air treatment has gained some importance in the postharvest treatment of some fruits. e.g. Mango at $48^{\circ} \mathrm{C}$ for 15 minutes considerably reduce the anthracnose and stem end rot (B. theobromae) and also eradicate the infection of fruit fly.

Drying of fruits: Many fruits can be stored for longer time after drying and can be kept free of disease because moisture is kept below a certain level during storage e.g. Grapes, plums, dates and figs, slices of fleshy fruits apples, peaches and apricots, etc.
Management through fungicides: Fungicides are a primary means of controlling postharvest diseases (Eckert and Ogawa, 1985). Their use worldwide is variable, comprising $26 \%$ of the pesticide market in Europe and Asia and 6\% in the United States (Jutsum, 1988). However, as harvested fruits and vegetables are commonly treated with fungicides to retard postharvest diseases, there is a greater likelihood of direct, human exposure to them than to other pesticides that are applied solely to protect foliage.

Fruit irradiation: Radiation treatments are meant for killing or weakening the pathogens present on the surface there by improving the shelf life of the fruits and vegetables. Among the ionizing radiation, gamma irradiation has been most successfully used for inhibiting the growth of pathogens inside fruit tissue. Irradiation ranging between $0.3 \mathrm{kGY}$ and $1.2 \mathrm{kGY}$ reduces the incidence of post-harvest storage disease of mango (Gloesporium \& Botryodiplodia) but a dose above $0.6 \mathrm{KGY}$ results in lenticels spotting and surface discoloration of the fruits. E.g. peaches, strawberries guava fruits (infected by $C$. gloeosporides to radiation at $100 \mathrm{krad}(1 \mathrm{kGY})$. Alternaria, Botrytis and Stemphylium can be controlled in vegetables in greenhouses with special UV-absorbing polyvinyl film.

Biological Control: Employing microbial antagonism offers one of the most effective means of controlling the post-harvest diseases without any adverse effect on the environment and the consumer. Control of pathogen through employing antagonist is popularly known as bio-control. Spraying with suspensions of $T$. harzianum, $T$. viride, Gliocladium roseum and Paceilomyces variotii resulted in a partial control of Botrytis in strawberry fruits and Alternaria rot in lemons. Three different types of interactions, competition for nutrients, competition for space, and inhibition by secondary metabolites, were observed with preharvest sprays of $B$. subtilis to control $C$. gleosporioides on avocado (Korsten et al., 1993). The main approaches used to improve the biocontrol of the postharvest diseases are $(a)$ manipulation of the environment, $(b)$ use of mixed cultures of antagonists, (c) physiological and genetic manipulation of antagonists, $(d)$ combining field and postharvest applications, $(e)$ manipulation of formulations, and $(f)$ integration with other methods (Wojciech et al., 2002). There are many bacterial and fungal bio agents which are currently used in postharvest diseases management (Table 2).

Fruit Coating with Vegetable / Edible Oil: Use of vegetable oils in plant disease control is a relatively recent development in the field of plant pathology. e.g. Castor, Linseed, Mustard, 
Table.1: Postharvest diseases of vegetables and fruits and their pathogens

\begin{tabular}{|l|l|}
\hline $\begin{array}{l}\text { Common Diseases of fruits } \\
\text { and vegetables }\end{array}$ & Pathogens \\
\hline Blue mould & Penicillium spp. \\
\hline Grey mould & Botrytis cinerea \\
\hline Bitter rot & Colletotrichum gloeosporioides \\
\hline Brown rot & Monilinia fructircola \\
\hline Soft rot of many fruits & Rhizopus nigricans, Penicillium expansum \\
\hline Black mould rot & Aspergillus niger \\
\hline Waxy and sour rot & Geotrichum candidum \\
\hline Brown rot of Banana & Botryodiplodia theobromar \\
\hline Fusarium rot & Fusarium spp. \\
\hline Fusarium rot of Jackfruit & Fusarium acuminatum \\
\hline Phoma rot & Phoma vexans \\
\hline Charcoal rot of mango & Rhizoctonia bataticola \\
\hline Black rot & Thielaviopsis paradoxa \\
\hline Anthracnose of Papaya & Colletotrichurn papayae \\
\hline Black soft rot & Mucor hiemalis \\
\hline Black spot & Curvularia tuberculata \\
\hline Sclerotium rot of beans & Sclerotium rolfsi \\
\hline Wet rot of Cowpea & Choanephora cucurbitarum \\
\hline Soft rot & Cunninghamella echinulata \\
\hline Cottony leak of pea & Phytophthora parasitica \\
\hline Cottony watery rot Ginger & Pythium aphanidermatum \\
\hline Soft rot of Ginger & Stachybotrys kampalensis \\
\hline Source: Narayanamy, & \\
\hline
\end{tabular}

(Source: Narayanasamy, 2006)

Table 2: Some postharvest diseases of vegetables and fruits and their bio control agents.

\begin{tabular}{|c|c|}
\hline Diseases & Biocontrol agents \\
\hline Blue mold & $\begin{array}{l}\text { Pseudomonas syringae } \\
\text { Pseudomonas cepacia, } \\
\text { Cryptococcus spp. } \\
\text { Pichia guilliermondii }\end{array}$ \\
\hline Gray mold & $\begin{array}{l}\text { Pseudomonas cepacia, C. laurentii, } \\
\text { C. flavus, C. albidus, } \\
\text { Acremonium breve, Pseudomonas cepacia }\end{array}$ \\
\hline $\begin{array}{l}\text { Mucor rot Green } \\
\text { mold }\end{array}$ & $\begin{array}{l}\text { Pichia guilliermondii, } \\
\text { C. laurentii, } \\
\text { C. flaws, C. albidus }\end{array}$ \\
\hline Rhizopus rot & Enterobacter cloacae \\
\hline Penicillium rot & Attenuated strains of Penicillium sp. \\
\hline Alternaria rot & Trichoderma sp. \\
\hline Brown rot & Bacillus subtilis \\
\hline Mucor rot & Pseudomonas cepacia \\
\hline Stem end rot & Bacillus subtilis \\
\hline Sour rot & $\begin{array}{l}\text { B. subtilis Trichoderma } \mathrm{sp} \text {. } \\
\text { B. Subtilis }\end{array}$ \\
\hline Green mold & $\begin{array}{l}\text { Bacillus subtilis } \\
\text { Pichia guilliennondii }\end{array}$ \\
\hline
\end{tabular}

(Source: Wilson et al., 1991) 
Sunflower, Safflower, Groundnut, mineral oils, Palmarosa, red thyme / liquid paraffin, etc. coated on harvested fruits to prevent entry of pathogen as well as decreasing respiration due to their antifungal activity. Composite coating of polysaccharides (cellulose, pectin, starch, alginate, and chitosan), proteins (casein, soy) and lipids (waxes, mineral oils) have been extensively used in controlling spoilage of fruits and vegetables. Waxing of certain fruits and vegetables is used mostly for enhancing appearance and reducing water loss by about 30 to 40 percent, especially if the commodity is exposed to less than optimal temperature and relative humidity conditions (Azizah et al., 2009). Sometimes the antioxidants are added to protect against oxidative rancidity, degradation and discoloration.

Natural Plant Products: The study of green plants of their antimicrobial activity has received little attention though such activity was known since ancient times. Neem leaves were kept in woolly cloths and grain store houses for preventing deterioration by moulds $\&$ pests and still today it is common practice. Baskets of fruits and vegetables are lined with Neem leaves for their protection against microbial attacks. It is believed that toxic substance emitted by the leaves keep the air remarkably free of pathogenic microorganisms. Like the same Neem oil is too good as the Neem leaf are for the management of the pathogens. Many researchers have shown the benefits of different garlic concentrations for controlling Aspergillus niger, Gliocladium roseum and Sclerotium rolfsii rots of Apple, peach and pear fruits (Singh and Tripathi, 2013).

\section{Conclusion}

A wide variety of pathogens cause postharvest disease in fruits and vegetables and can cause serious damage to them. Some of these pathogens infect produce before harvest and then remain silent or dormant until the conditions are more favourable for disease development after harvest. Other pathogens infect produce during and after harvest through surface injuries. In the development of strategies for postharvest disease control, it is imperative to take a step back and consider the production and postharvest handling systems in their entirety. Many preharvest factors directly and indirectly affect the development of postharvest disease, even in the case of infections initiated after harvest. Traditionally fungicides have played a central role in postharvest disease control. However, trends towards reducing the chemical usage in fruits and vegetables are forcing researchers to develop new strategies for the management of postharvest diseases. The results of many researchers study indicate that $27 \%$ of respondents send their products straight to the wholesaler without performing any postharvest handling activities. The various postharvest techniques applied to reduce the respiration and to stop the deterioration of fruits and vegetables is in the postharvest handling activity with the highest potential in reducing postharvest losses. But the knowledge to apply the measures to reduce the spoilage of the fruits and vegetables has to be in hands of the growers and sellers.

\section{References}

1. Azizah, O., Saari, N., Saleh, R., Bakar, J., Zainal, N.D. and Yacob, M. (2009). Postharvest Handling Practices on Selected Local Fruits and Vegetables at Different Levels of the Distribution Chain. J Agribus. Market. 2: 39-53.

2. Cappellini, R. A. and Ceponis, M. J. (1984). Postharvest losses in fresh fruits and vegetables. In: Postharvest Pathology of Fruits and Vegetables: Postharvest Losses in Perishable Crops. (Eds. Moline, H. E.). UC, Berkeley: Agriculture Experiment Station. pp. 24-30.

3. Eckert, J. W. and Ogawa, J. M. (1985). The chemical control of postharvest diseases: subtropical and tropical fruits. Annual Rev Phytopath. 23:421-54.

4. Eckert, J. W. and Ogawa, J. M. (1988). The chemical control of postharvest diseases. Deciduous fruits, berries, vegetables and root/ tuber crops. Annual Rev Phytopath.. 26: 433-69.

5. Gullino, M. L. and Kuijpers, Lam. (1994). Social and political implications of managing plant diseases with restricted fungicides in Europe. Annual Review of Phytopathology. 32:559-79.

6. Holmes, G. J., and Eckert, J. W. (1999). Sensitivity of Penicillium digitatum and $\mathrm{P}$. italicum to postharvest citrus fungicides in California. Phytopath. 89:716-21.

7. Jacobi, K.K., MacRae, E.A. and Hetherington, S.E. (2001). Postharvest heat disinfestation treatments of mango fruit. Scien Horticul. 89, 171-193.

8. Jutsum, A. R. (1988). Commercial application of biological control: Status and prospects. Philosoph Trans Royal Society London Ser. b. 318:357-373.

9. Kader, A.A. (2002). Postharvest Technology of Horticultural Crops (3rd Edition). UC Publication 3311. University of California, Division of Agriculture and Natural Resources, Oakland, California 94608. pp. 535

10. Korsten, L., de Villiers, E. E., de Jager, E. S., van Harmelen, M. W. S. and Heitmann, A. (1993). Biological control of litchi fruit 
diseases. South Africa Litchi Growers Assoc. b. 5: 36-40.

11. Narayanasamy, P. (2006). Postharvest Pathogens and Disease Management. John Wiley \& Sons, Inc., Hoboken, New Jersey.

12. Pathak, V.N. (1980). Diseases of Fruit Crops. Oxford \& IBH. New Delhi.

13. Prusky, D., Bazak, M. and Ben Arie, R. (1985). Development, persistence, survival and strategies for control of thiabendazole resistant strains of Penicillium expansum on pome fruits. Phytopath. 75:877-82.

14. Ragsdale, N. N. and Sisler, H. D. (1994). Social and political implications of managing plant diseases with decreased availability of fungicides in the United States. Annual Rev Phytopath. 32:545-57.

15. Singh, Rinki and Tripathi, Pramila (2013). A Review on Studies of Post-harvest Fungicides Diseases of Some Fruits. Intern J Agric Food Sci Technol. 4(7): 721-724.

16. Rosenberger, D. A. and Meyer, F. W. (1981). Postharvest fungicides for apples: development of resistance to benomyl, vinclozolin, and iprodione. Plant Disease. 65:1010-1013.

17. Tsai, W.H. (1969). Studies on ecology and physiology of papaya anthracnose and its control. J Taiwan Agric Res.18: 51- 57.

18. Vinas, I., Usall, J. and Sanchis, V. (1991). Tolerance of Penicillium expansum to postharvest fungicide treatments in apple packing houses in Lerida (Spain). Mycopathologia. 113:15-18.

19. Wilson, C.L., Wisniewski, M.E., Biles, C.L. McLaughlin, R., Chalutz, E. and Droby, S. (1991). Biological control of post-harvest diseases of fruits and vegetables: Alternatives to synthetic fungicides. Crop Protec. 10:172-177.

20. Wojciech, J. Janisiewicz and Korsten, Lise (2002). Biological Control of Postharvest Diseases of Fruits. Annual Rev Phytopath. 40:411-41. 